\title{
Urea kinetics in healthy women during normal pregnancy
}

\author{
BY IRENE S. M. MCCLELLAND, CHANDARIKA PERSAUD AND ALAN A. JACKSON \\ Department of Human Nutrition, University of Southampton, Southampton SO16 7PX
}

(Received 27 February 1996 - Revised 3 June 1996 - Accepted 8 July 1996)

\begin{abstract}
Urea kinetics were measured in normal women aged 22-34 years at weeks 16, 24 and 32 on either their habitual protein intake (HABIT) or a controlled intake of $60 \mathrm{~g}$ protein/d (CONTROL), using primed-intermittent oral doses of $\left[{ }^{15} \mathrm{~N}^{15} \mathrm{~N}\right]$ urea and measurement of plateau enrichment in urinary urea over $18 \mathrm{~h}$ (ID) or a single oral dose of $\left[{ }^{15} \mathrm{~N}^{15} \mathrm{~N}\right]$ urea and measurement of enrichment of urea in urine over the following $48 \mathrm{~h}$ (SD). The intake of protein during HABIT-ID (80 g/d) was greater than that on HABIT-SD (71 g/d); urea production as a percentage of intake was significantly greater at week 16 for HABIT-ID than HABIT-SD, whereas urea hydrolysis at week 16 was greater for HABIT-SD than HABIT-ID and urea excretion at week 32 was greater for HABIT-ID than HABITSD. The combined results for HABIT-ID and HABIT-SD showed a significant reduction in urea production at week 32 compared with week 24 . Urea excretion decreased significantly from week 16 to week 24 with no further decrease to week 32 and urea hydrolysis was significantly greater at week 24 than either week 16 or week 32. Compared with HABIT, on CONTROL there was a decrease in urea production at week 16, and urea excretion was significantly reduced at week 16. For all time periods urea production was closely related to the sum of intake plus hydrolysis. Hydrolysis was greatest at week 24 and closely related to urea production. There was a significant inverse linear relationship overall for hydrolysis as a proportion of production and excretion as a proportion of intake. The results show that on HABIT $N$ is more effectively conserved in mid-pregnancy through an increase in urea hydrolysis and salvage, and during late pregnancy through a reduction in urea formation. Lowering protein intake at any stage of pregnancy increased the hydrolysis and salvage of urea. The staging of these changes was later than that in pregnancy in Jamaica.
\end{abstract}

$\left[{ }^{15}\right.$ N]urea: Urea kinetics: Protein requirements: Pregnancy

For a mother to be able to sustain a pregnancy successfully requires that she is able to satisfy the nutritional and metabolic needs of her own body and that of the feto-placental unit. Extreme nutritional deprivation, either before or during pregnancy can limit the ability of the embryo and fetus to grow (Kramer, 1987; Rush, 1989). However, the extent to which more modest differences in maternal size or body composition at the start of pregnancy, or nutritional intake during pregnancy, might compromise either fetal growth or the functional capacity of the offspring is less clear (National Academy of Sciences, 1990; Barker, 1992). The definition of nutrient requirements during pregnancy in the human subject is inherently difficult. First, there are relatively small changes over relatively long periods of time. Second, in the short term, changes in maternal body composition might effectively buffer any effect of modest dietary influences. Consequently there is uncertainty in setting recommendations for dietary intakes during pregnancy (Department of Health and Social Security, 1979; Food and Agriculture Organization/World Health Organization/ United Nations University, 1985; Committee on Medical Aspects of Food Policy, 1991). The use of balance studies to determine requirements is not adequate because although balance has to be achieved in order to identify a diet as being adequate, balance of itself is 
not a sufficient criterion for the determination of adequacy (Rand et al. 1984; Food and Agriculture Organization/World Health Organization/United Nations University, 1985; Committee on Medical Aspects of Food Policy, 1991). In response to this difficulty increased use has been made of more dynamic measures of amino acid and protein metabolism to characterize overall metabolic well-being (Young et al. 1989; Millward, 1992; Jackson, 1995).

For pregnancy there is relatively little information available (Hytten \& Leitch, 1971; Calloway, 1974; National Academy of Sciences, 1990). The needs for protein for net deposition in maternal tissues and the growth of the fetus and placenta are not distributed evenly throughout pregnancy and animal studies indicate preferential deposition of maternal protein early in pregnancy, which potentially can be utilized by the placenta and fetus at a later stage (Naismith \& Morgan, 1976; Mayel-Afshar \& Grimble, 1983).

In a normal pregnancy the average weight gain is about $12.5 \mathrm{~kg}$ of which $0.9 \mathrm{~kg}$ is protein, giving an average gain of $3 \mathrm{~g} / \mathrm{d}$ or $480 \mathrm{mg} \mathrm{N} / \mathrm{d}$ (Hytten \& Leitch, 1971). Balance studies indicate a positive daily balance of $1-3 \mathrm{~g} \mathrm{~N} / \mathrm{d}$ during late pregnancy (King, 1975; Johnstone et al. 1981). Positive balance is associated with a reduction in the rate of urea loss in urine, which has been presumed to reflect a decrease in urea production. However, changes in urea excretion may not necessarily reflect changes in urea production because when the body is seeking to economize on $\mathbf{N}$ there may be an increase in the salvage of urea- $\mathrm{N}$ following enhanced hydrolysis of urea by the colonic microflora (Langran et al. 1992; Jackson, 1993). Urea production has been measured at some time during pregnancy in three studies (Kalhan et al. 1982; Olufemi et al. 1991; Forrester et al. 1994). Forrester et al. (1994) measured urea kinetics longitudinally in pregnant Jamaican women and found that protein intake did not change during pregnancy, but urea hydrolysis was significantly increased early in pregnancy, falling to levels similar to the non-pregnant state by the third trimester. In the other two studies urea production in the third trimester was $40 \%$ lower than postpartum when measured towards the end of a $17 \mathrm{~h}$ fast (Kalhan et al. 1982) or in the post-absorptive state (Olufemi et al. 1991). These studies suggest that any changes in late gestation might be relatively modest, without precluding more marked changes earlier in pregnancy (Forrester et al. 1994).

In the present study urea kinetics have been measured longitudinally in women on their habitual dietary intake at 16, 24 and 32 weeks gestation compared with women in whom protein intake was controlled at $60 \mathrm{~g}$ protein/d, the recommended daily amount (RDA) at the time the studies were carried out (Department of Health and Social Security, 1979). Although scientifically it might have been desirable to reduce the protein intake to the physiological minimum requirement, about $40 \mathrm{~g}$ protein/d, this was not acceptable ethically.

\section{METHODS}

\section{Subjects}

The studies were carried out in eighteen women aged 22-34 years. Sixteen of the eighteen women were recruited from the antenatal booking clinic of the Princess Anne Hospital, Southampton and two were recruited through personal contact. The studies had the approval of the Southampton Hospitals and South West Hampshire Health Authority Ethical Subcommittee. The women agreed to participate after the nature of the investigations had been explained to them. All the women were in good health with no obvious medical problems or complications of pregnancy. They had been consuming a normal diet and none had been taking any form of medication before recruitment. During 
Table 1. The age, parity and gestational weight of eighteen women who participated in one of two protocols to measure urea kinetics, with the gender and weight of the newborn infant

\begin{tabular}{|c|c|c|c|c|c|c|c|c|}
\hline Subject no. & Age (years) & Primiparous & $\begin{array}{c}\text { Wt at } 16 \\
\text { weeks }(\mathrm{kg})\end{array}$ & $\begin{array}{l}\text { Wt gain weeks } \\
16 \text { to } 24(\mathrm{~kg})\end{array}$ & $\begin{array}{c}\text { Weight gain } \\
\text { weeks } 24 \text { to } 32(\mathrm{~kg})\end{array}$ & Protocol & $\begin{array}{l}\text { Sex of } \\
\text { infant }\end{array}$ & $\begin{array}{l}\text { Birth } \\
\text { wt (g) }\end{array}$ \\
\hline 1 & 29 & YES & $56 \cdot 0$ & 5.0 & 3.5 & 1 & $\mathbf{M}$ & 3450 \\
\hline 2 & 29 & NO & 62.7 & 1.7 & 2.7 & 1 & $\mathbf{F}$ & 3060 \\
\hline 3 & 32 & YES & 60.1 & $5 \cdot 0$ & $7 \cdot 1$ & 1 & M & 3900 \\
\hline 4 & 31 & NO & 56.0 & 5.0 & 5.5 & 1 & $\mathbf{F}$ & 3200 \\
\hline 5 & 30 & NO & 54.4 & $4 \cdot 1$ & 3.1 & 1 & $\mathbf{M}$ & 2680 \\
\hline 6 & 22 & No & 68.2 & 4.8 & -0.8 & 1 & $F$ & 3940 \\
\hline 7 & 28 & NO & 68.0 & 5.5 & $3 \cdot 2$ & 1 & F & 3970 \\
\hline 8 & 23 & YES & 70.4 & 8.0 & 6.4 & 1 & $\mathbf{M}$ & 3420 \\
\hline 9 & 26 & YES & 64.1 & $8 \cdot 3$ & $6 \cdot 2$ & 1 & $\mathbf{M}$ & 3680 \\
\hline 10 & 26 & YES & 60.0 & 0 & 3.0 & 1 & $\mathbf{M}$ & 2980 \\
\hline 11 & 27 & YES & 54.6 & 1.6 & 6.6 & 2 & $\mathbf{M}$ & 3495 \\
\hline 12 & 33 & NO & 57.2 & 2.8 & 2.8 & 2 & $\mathbf{M}$ & 2200 \\
\hline 13 & 34 & NO & 63.0 & 5.0 & 2.2 & 2 & F & 4045 \\
\hline 14 & 26 & YES & 66.2 & 6.0 & 3.8 & 2 & $F$ & 4000 \\
\hline 15 & 30 & NO & 75.6 & 6.8 & 6.4 & 2 & $\mathbf{M}$ & 3510 \\
\hline 16 & 28 & YES & 61.8 & 6.0 & 3.8 & 2 & $\mathbf{M}$ & 3280 \\
\hline 17 & 33 & NO & 66.4 & 3.0 & 1.2 & 2 & F & 4325 \\
\hline 18 & 28 & YES & 61.8 & 3.6 & $2 \cdot 2$ & 2 & $\mathbf{M}$ & 3170 \\
\hline
\end{tabular}

Protocol 1, primed intermittent doses of labelled urea; protocol 2, single doses of labelled urea.

their pregnancies some women were prescribed medication for indigestion or 'heartburn' whilst others were prescribed Fe tablets or injections. No constraints were placed on the behaviour of the women during the studies, which were carried out in their own homes. The characteristics of the subjects and protocols in which they participated are shown in Table 1.

\section{Protocols}

The objective of the study was to measure urea kinetics at three different stages of pregnancy on the women's habitual protein intake and to compare these results with urea kinetics in women in whom dietary intake of protein was controlled at $60 \mathrm{~g} / \mathrm{d}$ (Department of Health and Social Security, 1979). At the end of the first study it was clear that the variation in urea kinetics between women was sufficiently great that it might be difficult to identify differences on a group basis on the $60 \mathrm{~g}$ protein/d intake. Therefore, the second part of the study was designed as an intervention study in which urea kinetics were measured in the same women before and after taking the controlled protein intake. This placed greater demands on their participation and they identified a preference for a less intrusive approach to the measurement of urea kinetics in which a single dose of labelled urea was taken and urine collected for a period of $48 \mathrm{~h}$ (Jackson et al. 1993).

Protocol 1: primed intermittent doses of labelled urea. The objective was to determine urea kinetics longitudinally throughout pregnancy in women taking their habitual intake of energy and protein (HABIT-ID). The women completed a questionnaire and a $2 \mathrm{~d}$ dietary recall to provide information on food preferences, the typical pattern of food consumption and an estimate of habitual intake. Dietary analysis for individual macronutrient consumption was carried out using the COMPEAT computer package (Nutrition Service 
Ltd, London). For the day before the study and the day of the study itself food was provided to the women. All food was prepared and delivered to the subjects' homes. The food was provided as five isonitrogenous meals daily, and was composed of ordinary foodstuffs. On day 1 the women ate the food at their preferred meal times but on day 2 the food was consumed at intervals of $3 \mathrm{~h}$ from 06.00 hours. During the final $24 \mathrm{~h}$ of each study period urea kinetics were measured using the primed-intermittent presentation of $\left.{ }^{15} \mathrm{~N}^{15} \mathrm{~N}\right]$ urea (99\% atoms ${ }^{15} \mathrm{~N}$ : Cambridge Isotope Laboratories, Andover, MA, USA). An accurately known amount of $\left[{ }^{15} \mathrm{~N}^{15} \mathrm{~N}\right]$ urea was made up in sterile water and kept on ice until ready for use. At midnight a priming dose of isotopic urea equivalent to $15 \mathrm{~h}$ of intermittent doses $(28.5 \mathrm{mg})$ was given orally to shorten the time taken to achieve a plateau in isotopic enrichment in urinary urea. From 06.00 hours single doses of urea $(5.5 \mathrm{mg})$ were administered at $3 \mathrm{~h}$ intervals until 15.00 hours. Urine was collected from 21.00 hours to midnight, immediately before the administration of the first dose of isotope, for the measurement of background enrichment, between midnight and 06.00 hours and at $3 \mathrm{~h}$ intervals from 06.00 hours until 21.00 hours.

Protocol 2: single doses of labelled urea. The objective was to determine urea kinetics longitudinally throughout pregnancy in women taking a controlled intake of $60 \mathrm{~g}$ protein/d. An estimate of the habitual energy and protein intake and the amount and type of food was made for each woman using a $1 \mathrm{~d}$ dietary recall while information on food preferences was obtained by questionnaire. The study period lasted for $7 \mathrm{~d}$. During the first $48 \mathrm{~h}$ urea kinetics were measured using the single-dose method, while the women were consuming their habitual intake and an accurate written record was kept of their actual ad libitum intake (HABIT-SD). The women were then placed on the controlled diet, designed to provide their habitual intake of energy and $60 \mathrm{~g}$ protein/d for $6 \mathrm{~d}$. Urea kinetics were measured again during the final $48 \mathrm{~h}$ period using the single-dose method (CONTROLSD). The test diets were prepared from ordinary foodstuffs and were delivered to the women in their homes. If during the study, the women developed a dislike for any of the foods an alternative of similar protein composition was provided. Measurements of urea kinetics were made with the oral presentation of a single dose of $\left[{ }^{15} \mathrm{~N}^{15} \mathrm{~N}\right] \mathrm{urea}(99 \%$ atoms ${ }^{15} \mathrm{~N}$; Cambridge Isotope Laboratories). The $\left[{ }^{15} \mathrm{~N}^{15} \mathrm{~N}\right]$ urea was made into solution using approximately $23 \mathrm{ml}$ sterile water and kept on ice until ready for use. A specimen of urine was taken for the measurement of baseline enrichment and the $\left[{ }^{15} \mathrm{~N}^{15} \mathrm{~N}\right] \mathrm{urea}, 100 \mathrm{mg}$, was taken orally at 09.00 hours. All urine passed in the following $48 \mathrm{~h}$ was collected in two portions of $24 \mathrm{~h}$ each.

\section{Urea kinetics}

Analyses. All specimens of urine were collected into acidified containers and stored frozen until analysed. The concentration of urea and $\mathrm{NH}_{3}$ in urine was measured using the Berthelot method (Kaplan, 1965) and urea-N was isolated from urine for mass spectrometry using short ion-exchange column chromatography (Jackson et al. 1980). $\mathrm{N}_{2}$ gas was liberated from urea by reaction with alkaline hypobromite. In this reaction $\mathrm{N}$ is released from urea in a monomolecular reaction (Walser et al. 1954), hence the relative proportions of $\left[{ }^{15} \mathrm{~N}^{15} \mathrm{~N}\right]$ urea, $\left[{ }^{15} \mathrm{~N}^{14} \mathrm{~N}\right]$ urea and $\left[{ }^{14} \mathrm{~N}^{14} \mathrm{~N}\right]$ urea can be determined. Measurements of enrichment were carried out in a triple-collector isotope-ratio mass spectrometer (SIRA 10; VG Isogas, Winsford, Ches.). 


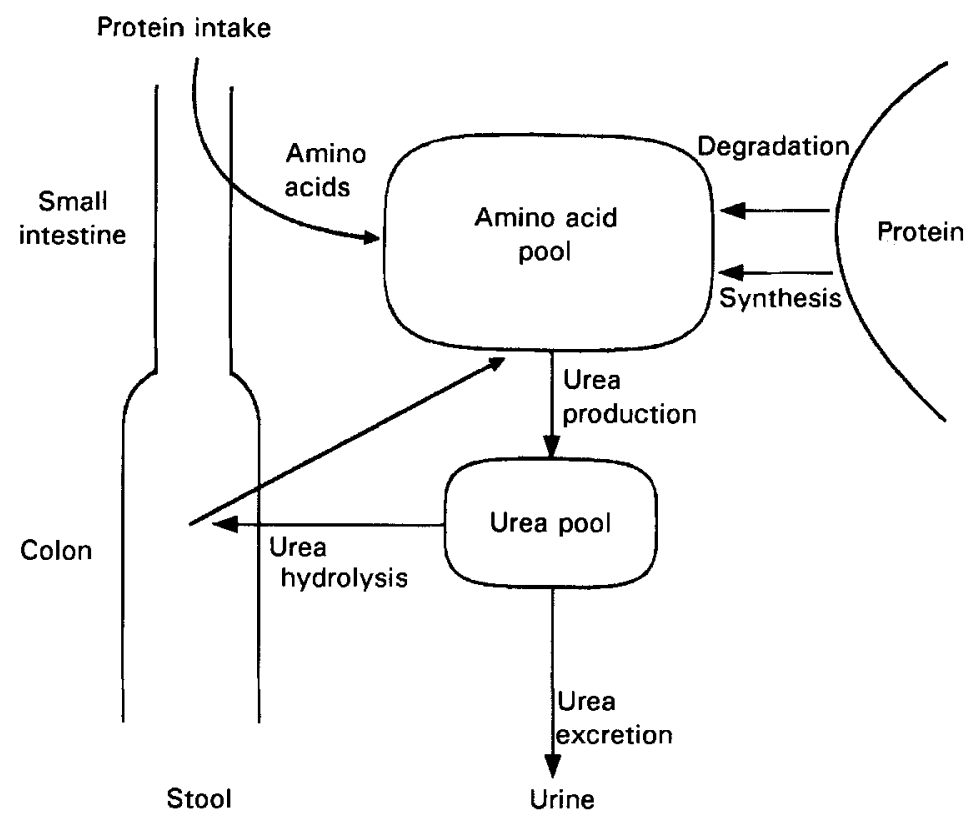

Fig. 1. Urea kinetics are characterized within a metabolic model which consists of the exchanges and interaction amongst an amino acid pool, a protein pool and a urea pool. Amino acids derived from ingested protein contribute to the amino acid pool, which also receives inputs from protein degradation and the salvage of urea-nitrogen. Amino acids are either used for protein synthesis or oxidized with the formation of urea. A portion of the urea produced is excreted in urine and a portion passes to the colon where it is hydrolysed by the metabolic activity of the colonic microflora.

Calculations. The model of protein, amino acid and $\mathrm{N}$ metabolism within which urea kinetics are determined is shown in Fig. 1.

For protocol 1 (primed intermittent doses of labelled urea) urea kinetics were calculated by the model of Jackson et al. (1984). Ingested protein is made available to metabolism as amino acids, which mix with the general body pool; amino acids also derive from protein degradation. Once an isotopic steady-state has been achieved, the dilution of an intermittent dose of $\left[{ }^{15} \mathrm{~N}^{15} \mathrm{~N}\right]$ urea gives a measure of the rate of urea appearance in the urea pool, that is the rate of urea production in the body. Only a proportion of the urea produced is excreted in the urine. The difference between the urea produced and that excreted is presumed to have been hydrolysed in the bowel with the $\mathrm{N}$ being returned to the general metabolic pool of $\mathrm{N}$ and being available for further metabolic interaction. Details of the calculations are given by Jackson et al. (1984).

For protocol 2 (single doses of labelled urea) urea kinetics were calculated by the model of Jackson et al. (1993). A known amount of isotopically-labelled $\left[{ }^{15} \mathrm{~N}^{15} \mathrm{~N}\right] \mathrm{urea}$ mixes freely with the urea pool of the body and is presumed to trace reliably the fate of the urea in that pool. The labelled urea is cleared from the pool in $36-48 \mathrm{~h}$ and the proportion of the dose lost in the urine is similar to the proportion of endogenously formed urea which is lost in the urine. From a knowledge of the amount of urea in the urine and the proportion of the labelled urea lost in the urine, the rate of endogenous urea formation can be calculated and by difference the amount of urea hydrolysed by the colonic microflora can be derived. Details of the calculations are given by Jackson et al. (1993).

The assumption is made that an oral dose of $\left[{ }^{15} \mathrm{~N}^{15} \mathrm{~N}\right]$ urea is absorbed intact, without any hydrolysis of the label before absorption. This assumption is not justified in individuals 
in whom there is gastric infection with Helicobacter pylori (Graham et al. 1987). The hydrolysis of the dose before absorption can be determined by measuring the ratio of the rate at which labelled urea-N derived from urea hydrolysis is returned to urea formation, relative to the measured rate of urea formation (Hibbert et al. 1992). The assumption is considered not to hold when this ratio exceeds $15 \%$ (Hibbert et al. 1992), and in two studies the data were excluded from analysis because this condition applied and they were rejected as unsatisfactory.

Comparisons between groups of data were carried out using ANOVA and paired $t$ tests as appropriate. Results are reported as means and standard deviations. Although results might usually be expressed as $\mathrm{mg} \mathrm{N} / \mathrm{kg}$ per $\mathrm{d}$, this presents problems in pregnancy when there are complex changes in weight and body composition (Thompson \& Halliday, 1992). There is no completely satisfactory way around this difficulty. In order to reduce any chance of misinterpretation the results have been expressed in relation to the weight of each subject at the time of the first study.

\section{RESULTS}

The results are reported for the studies which were completed satisfactorily and represent a total of fifty-four measurements of urea kinetics made in eighteen women. Not all women were able to complete the entire series and ten women have been excluded from the analysis either for this reason or because of clinical complications. All the women who completed the studies had normal pregnancies and gave birth to babies with a mean birth weight of 3461 (SD 536) g (Table 1). The women accepted the diets and there were no major problems with compliance. Great emphasis was placed on the importance of complete urine collections. We were not willing to give pregnant women a marker to validate the completeness of urine collections, but based on the measurement of urinary creatinine (data not shown) we have no reason to believe that there were any failures which would seriously prejudice the data or the interpretations.

\section{Protocol 1: primed intermittent doses of labelled urea}

There were five primiparous and five multiparous women in the group and the average ages were 27 and 28 years respectively (Table 1 ). At week 16 of gestation both the primiparous women and the multiparous women weighed $62 \mathrm{~kg}$ on average. Gains in weight between week 16 and week 24 were 5.3 and $5.2 \mathrm{~kg}$ for the primiparous and multiparous women respectively and between 24 and 32 weeks 5.2 and $2.7 \mathrm{~kg}$. The average weight of the infants for the primiparous women was $3486 \mathrm{~g}$ and for the multiparous women $3370 \mathrm{~g}$. There were five male and five female offspring in the group.

The levels of plateau enrichments in urinary urea were identified by visual inspection and a satisfactory plateau was achieved in all the studies. The coefficient of variability for the enrichment in mass 30:28 at plateau was $14 \%$ on average (range 2-26\%). Table 2 shows the results for urea kinetics for the women at weeks 16, 24 and 32 of pregnancy. There were no significant differences in protein intake between trimesters $(13.3,12.9$, $12.8 \mathrm{~g} \mathrm{~N} / \mathrm{d}$, approximately $80 \mathrm{~g}$ protein/d), nor in urea production. Urinary excretion of urea demonstrated a phasic response. Excretion at week 24 was significantly less than at week 16, a $25 \%$ reduction. There was an increase in excretion between week 24 and week 32 , which did not achieve statistical significance. The largest differences between the different stages of pregnancy were seen for urea hydrolysis. There was a statistically significant increase from week 16 to week $24(190 \%)$ and a statistically significant fall from week 24 to week 32, with the result that there was no difference between week 16 and 
Table 2. Urea kinetics ( $m g$ nitrogen/kg per d) were measured in ten women by primed intermittent oral doses of $I^{15} N^{15}$ NJurea at weeks 16,24 and 32 of pregnancy whilst they were consuming their habitual intake of $80 \mathrm{~g}$ protein/d (HABIT-ID)

\begin{tabular}{|c|c|c|c|c|c|c|c|c|c|c|c|c|c|c|c|}
\hline \multirow{2}{*}{$\begin{array}{c}\text { Week of } \\
\text { pregnancy ... } \\
\text { Subject no. }\end{array}$} & \multicolumn{3}{|c|}{$\mathbf{N}$ intake } & \multicolumn{3}{|c|}{ Urea production } & \multicolumn{3}{|c|}{ Urea excretion } & \multicolumn{3}{|c|}{ Urea hydrolysis } & \multicolumn{3}{|c|}{$\begin{array}{l}\mathrm{N} \text { intake plus } \\
\text { urea hydrolysis }\end{array}$} \\
\hline & 16 & 24 & 32 & 16 & 24 & 32 & 16 & 24 & 32 & 16 & 24 & 32 & 16 & 24 & 32 \\
\hline 1 & 329 & 339 & 339 & 254 & 377 & 248 & 192 & 151 & 211 & 62 & 226 & 37 & 391 & 565 & 376 \\
\hline 2 & 195 & 112 & 97 & 195 & 123 & 112 & 125 & 59 & 55 & 70 & 64 & 58 & 265 & 176 & 155 \\
\hline 3 & 214 & 236 & 226 & 192 & 190 & 182 & 128 & 105 & 118 & 64 & 85 & 65 & 278 & 321 & 291 \\
\hline 4 & 218 & 208 & 208 & 199 & 194 & 218 & 161 & 129 & 146 & 38 & 65 & 72 & 256 & 273 & 280 \\
\hline 5 & 236 & 235 & 235 & 200 & 212 & 211 & 140 & 106 & 152 & 60 & 106 & 59 & 296 & 341 & 294 \\
\hline 6 & 172 & 288 & 243 & 203 & 209 & 207 & 159 & 83 & 138 & 44 & 126 & 69 & 216 & 414 & 312 \\
\hline 7 & 203 & 167 & 167 & 169 & 177 & 201 & 132 & 94 & 134 & 37 & 83 & 68 & 240 & 250 & 235 \\
\hline 7 & 193 & 138 & 161 & 142 & 157 & 168 & 113 & 89 & 155 & 30 & 68 & 13 & 223 & 206 & 174 \\
\hline 9 & 204 & 176 & 212 & 180 & 168 & 131 & 142 & 86 & 90 & 38 & 81 & 42 & 242 & 257 & 254 \\
\hline 10 & 174 & 176 & 189 & 178 & 180 & 143 & 131 & 159 & 96 & 47 & 21 & 47 & 221 & 197 & 236 \\
\hline Mean & 214 & 208 & 208 & 191 & 199 & 182 & 142 & $106 * *$ & 129 & 49 & $93^{*}$ & $53 \dagger$ & 263 & 300 & 261 \\
\hline SD & 45 & 69 & 63 & 29 & 68 & 43 & 23 & 32 & 42 & 14 & 54 & 18 & 52 & 118 & 65 \\
\hline
\end{tabular}

Mean values were significantly different from those at 16 weeks: $* P<0.05$, ${ }^{* *} P<0.01$.

Mean value was significantly different from that at 24 weeks: $+P<0-05$.

Table 3. Urea kinetics were measured at week 16, week 24 and week 32 of pregnancy in women who were taking their habitual protein intake, either with primed intermittent oral doses of $\left.I^{15} N^{15} N\right]$ urea (HABIT-ID), or a single oral dose of $\left[{ }^{15} N^{15} N\right]$ rea, either on their habitual intake of protein (HABIT-SD) or a restricted intake of $60 \mathrm{~g} / \mathrm{d}$ (CONTROL-SD)§

\begin{tabular}{lcccc}
\hline \hline & $\begin{array}{c}\text { Production: intake } \\
(\%)\end{array}$ & $\begin{array}{c}\text { Excretion: intake } \\
(\%)\end{array}$ & $\begin{array}{c}\text { Excretion: production } \\
(\%)\end{array}$ & $\begin{array}{c}\text { Hydrolysis: production } \\
(\%)\end{array}$ \\
\hline Week 16 & & & & 26 \\
HABIT-ID & 91 & 68 & 75 & 40 \\
HABTT-SD & $121^{*}$ & 70 & 50 & 44 \\
CONTROL-SD & 101 & 57 & & $45 \dagger \dagger \dagger$ \\
Week 24 & & & $55 \dagger \dagger \dagger$ & 55 \\
HABIT-ID & 98 & 54 & 45 & 51 \\
HABIT-SD & 122 & 57 & 49 & $30+\ddagger$ \\
CONTROL-SD & 114 & 51 & $70 \ddagger \ddagger$ & 54 \\
Week 32 & 91 & 64 & 56 & 52 \\
HABIT-ID & 93 & 50 & 48 & \\
HABIT-SD & 111 & 52 & & \\
CONTROL-SD & & & & \\
\hline
\end{tabular}

Mean value was significantly different from that for HABIT-ID (ANOVA and post hoc $t$ test): $* P<0.05$.

Mean values were significantly different from those at week 16 (ANOVA and post hoc $t$ test: $\dagger \dagger \dagger P<0.001$.

Mean values were signficantly different from those at week 24 (ANOVA and post hoc $t$ test): $\$+P<0.01$.

$\S$ For details of subjects and procedures, see Table 1 and pp. 166-170.

week 32. The relationship between protein intake and urea production remained fairly constant throughout pregnancy, with production being 91-98 \% of $\mathrm{N}$ intake (Table 3). Urea excretion was $68 \%$ of intake at week 16 of pregnancy, falling significantly to $54 \%$ of intake at week 24 and increasing at week 32 when it was $64 \%$ of intake. However, there were substantial differences in the disposal of urea between excretion and hydrolysis, with hydrolysis being $26 \%$ of production at week 16, increasing to $45 \%$ of production at week 
24 and falling to about $30 \%$ of production by week 32 . The groups were too small to identify differences in kinetics in relation to parity, weight gain or weight of the offspring.

\section{Protocol 2: single doses of labelled urea}

There were four primiparous and four multiparous women in the group and the average ages were 27 and 32.5 years respectively (Table 1). At 16 weeks of gestation the primiparous women weighed $61 \mathrm{~kg}$ and the multiparous women weighed $66 \mathrm{~kg}$ on average. Gains in weight between weeks 16 and 24 were 4.3 and $4.4 \mathrm{~kg}$ for the primiparous and multiparous women respectively and between 24 and 32 weeks the corresponding values were 4.1 and $3.1 \mathrm{~kg}$. The average weight of the infants for the primiparous women was $3486 \mathrm{~g}$ and for the multiparous women $3520 \mathrm{~g}$. There were five male and three female offspring in the group.

Initially urea kinetics were measured when the women were on their habitual protein intake (HABIT-SD) and then again after taking a restricted intake of protein $(60 \mathrm{~g} / \mathrm{d})$ for $5 \mathrm{~d}$ (CONTROL-SD). Urea kinetics were measured on each occasion by giving a single oral dose of labelled urea and following the excretion of label in urine over $48 \mathrm{~h}$. The habitual intake of protein was not different between trimesters $(11.2,12.3,10.9 \mathrm{~g} \mathrm{~N} / \mathrm{d}, 71 \mathrm{~g}$ protein/d on average; Table 4).

On HABIT-SD, urea production did not change between week 16 and week 24, but there was a statistically significant decrease from week 24 to week 32 of abut $30 \%$. Urea excretion decreased progressively from week 16 to week 32 , by $28 \%$, and the difference between week 16 and week 32 was statistically significant. Urea hydrolysis was greatest at week 24,135 and $175 \%$ of week 16 and week 32 respectively, and the difference between week 24 and week 32 was highly statistically significant.

On the CONTROL-SD ( $60 \mathrm{~g}$ protein/d) there were no differences in urea production or urea excretion between trimesters. Urea hydrolysis was greatest at week 24 , but the

Table 4. Urea kinetics (mg nitrogen/kg per d) were measured at weeks 16, 24 and 32 of pregnancy in eight women using a single oral dose of $\left[{ }^{15} N^{15} N\right]$ urea, while they were taking their habitual protein intake of $71 \mathrm{~g} / d$ (HABIT-SD), and again after $5 d$ on a diet which provided $60 \mathrm{~g}$ protein/d (CONTROL-SD)\&

(Values are means and standard deviations)

\begin{tabular}{|c|c|c|c|c|c|c|c|c|c|c|}
\hline & \multicolumn{2}{|c|}{$\mathrm{N}$ intake } & \multicolumn{2}{|c|}{$\begin{array}{c}\text { Urea } \\
\text { production }\end{array}$} & \multicolumn{2}{|c|}{$\begin{array}{c}\text { Urea } \\
\text { excretion }\end{array}$} & \multicolumn{2}{|c|}{$\begin{array}{c}\text { Urea } \\
\text { hydrolysis }\end{array}$} & \multicolumn{2}{|c|}{$\begin{array}{c}\mathrm{N} \text { intake plus } \\
\text { urea } \\
\text { hydrolysis }\end{array}$} \\
\hline & Mean & SD & Mean & $\mathrm{SD}$ & Mean & $\mathrm{SD}$ & Mean & $\mathrm{SD}$ & Mean & SD \\
\hline \multicolumn{11}{|l|}{ Week 16} \\
\hline HABIT-SD & 176 & 46 & 204 & 53 & 121 & 41 & 83 & 41 & 259 & 54 \\
\hline CONTROL-SD & 153 & 15 & 155 & 39 & $87 \ddagger$ & 24 & 68 & 28 & 221 & 39 \\
\hline \multicolumn{11}{|l|}{ Week 24} \\
\hline HABIT-SD & 195 & 60 & 224 & 36 & 102 & 41 & 120 & 32 & 316 & 74 \\
\hline CONTROL-SD & 153 & 15 & 175 & 67 & 76 & 28 & 98 & 77 & 251 & 84 \\
\hline \multicolumn{11}{|l|}{ Week 32} \\
\hline HABIT-SD & 175 & 35 & $159 * * *$ & 43 & $87 \dagger$ & 27 & $72 * * *$ & 37 & 247 & 54 \\
\hline CONTROL-SD & 153 & 15 & 168 & 57 & $79^{\prime}$ & 27 & 90 & 49 & 243 & 49 \\
\hline
\end{tabular}

Mean values were significantly different from those at week 24 (ANOVA and post hoc $t$ test): $* * * P<0.001$.

Mean value was significantly different from that at week 16 (ANOVA and post hoc $t$ test): $\dagger P<0.05$.

Mean value was significantly different from that for HABIT-SD (ANOVA and post hoc $t$ test): $\ddagger P<0.05$.

$\S$ For details of subjects and procedures, see Table 1 and pp. 166-170. 
differences between the different periods were relatively small and none were statistically significant.

\section{Comparison between protocol 1 (the intermittent-dose method) and protocol 2 (the single-dose method)}

The results for urea kinetics in HABIT-ID were compared with HABIT-SD. The groups were very similar in terms of weight and weight changes during pregnancy. Although the HABIT-SD subjects ingested less protein, the difference was not statistically significant, but urea production as a percentage of $\mathrm{N}$ intake was significantly higher for HABIT-SD at week $16(P=0.042)$. The only other differences in any aspect of urea kinetics between the two groups were in urea hydrolysis at week 16 and urea excretion at week 32 . At week 16 urea hydrolysis was significantly greater for HABIT-SD than HABIT-ID $(P=0.026)$. During week 32 urea excretion was significantly greater for HABIT-ID than HABIT-SD $(P=0.027)$. These differences probably reflect the differences in protein intake. When HABIT-ID and HABIT-SD were combined (Table 5) there was a significant decrease in urea production at week 32 compared with week $24(P=0.03)$ and a marginal reduction compared with week $16(P=0.08)$. Urea excretion was significantly reduced at week 24 $(P=0.017)$ and marginally at week $32(P=0.079)$ compared with week 16 . There was a significant increase in urea hydrolysis at week 24 compared with either week 16 $(P=0.0049)$ or week $32(P=0.0024)$.

\section{Comparison between habitual and controlled protein intake}

For CONTROL-SD at 16 weeks, urea production was reduced compared with HABIT-SD at a marginal level of statistical significance $(P=0.058)$; however, there was a statistically significant reduction in urea excretion for CONTROL-SD $(P=0.0094)$. Differences of

Table 5. Comparison of urea kinetics in ten non-pregnant and eighteen pregnant women taking either their habitual intake of protein, or the recommended daily allowances (Department of Health and Social Security, 1979) of protein of $55 \mathrm{~g} / \mathrm{d}$ for non-pregnant women (data from McClelland \& Jackson, 1996) and $60 \mathrm{~g} / \mathrm{d}$ for pregnant women§

\begin{tabular}{|c|c|c|c|c|c|c|c|c|}
\hline & \multicolumn{4}{|c|}{ Habitual protein intake } & \multicolumn{4}{|c|}{ Controlled protein intake } \\
\hline & Non-pregnant & Week 16 & Week 24 & Week 32 & Non-pregnant & Week 16 & Week 24 & Week 32 \\
\hline $\begin{array}{l}\text { Intake } \\
\text { (mg N/kg per d) }\end{array}$ & 181 & 197 & 202 & 193 & 153 & $153^{* *}$ & $153^{* *}$ & $153^{* *}$ \\
\hline $\begin{array}{l}\text { Urea production } \\
\text { (mg N/kg per d) }\end{array}$ & 200 & 197 & 210 & $172 \dagger+\ddagger$ & 186 & $155^{* *}$ & 175 & 168 \\
\hline $\begin{array}{l}\text { Urea excretion } \\
\text { (mg N/kg per d) }\end{array}$ & 124 & 133 & $105+\dagger$ & $110 \dagger$ & 111 & $87 * * *$ & $76^{*}$ & $79 *$ \\
\hline $\begin{array}{l}\text { Urea hydrolysis } \\
\text { (mg N/kg per d) }\end{array}$ & 76 & 64 & $105+\dagger \dagger$ & $62 \ddagger \ddagger$ & 74 & 68 & 98 & $90^{*}$ \\
\hline Production (\% intake) & 112 & 104 & 108 & 92 & 122 & 101 & 114 & 111 \\
\hline $\begin{array}{l}\text { Excretion } \\
\text { (\% production) }\end{array}$ & 62 & 68 & 51 & 63 & 59 & 56 & $49 * *$ & $48^{* * *}$ \\
\hline
\end{tabular}

Mean values were significantly different from those of the equivalent stage of pregnancy on the habitual protein diet (unpaired $t$ test): $* P<0.08, * * P<0.05, * * * P<0.01$.

Mean values were significantly different from those at week $16: \uparrow P<0.08, \dagger \dagger P<0.05, \dagger+\dagger P<0.01$.

Mean values were significantly different from those at week $24: \ddagger \ddagger P<0.05, \ddagger \ddagger \ddagger>0.01$.

$\S$ For details of subjects and procedures, see Table 1 and pp. 166-170. 
borderline statistical significance were seen for urea production $(P=0.07)$ and urea excretion $(P=0.047)$ between the two diets at week 24 . There were no statistically significant differences in urea production and excretion at week 32 . There were no differences in urea hydrolysis between the two diets at weeks 16, 24 or 32.

When CONTROL-SD was compared with all the women on their habitual intake (HABIT-ID and HABIT-SD; Table 5) urea production was significantly less on CONTROL-SD at week $16(P=0.021)$, and urea excretion was significantly less at week $16(P=0.0015)$, and marginally less at week $24(P=0.053)$ and week $32(P=0.062)$. Urea hydrolysis was marginally higher on CONTROL-SD at week $32(P=0.075)$. The results were compared with those obtained in non-pregnant women consuming their habitual diet or a diet in which the protein content was restricted to $55 \mathrm{~g} / \mathrm{d}$ (McClelland \& Jackson, 1996). There was very little difference in the pattern of response to the $55 \mathrm{~g}$ protein/d diet in the non-pregnant women and the changes seen at week 16 in the pregnant women on $60 \mathrm{~g}$ protein/d.

For every aspect of urea kinetics there was considerable variation between individuals. There are a number of factors which might have contributed towards this variability, but the groups were too small to identify their possible contribution with any confidence. However, the protein intake of HABIT-SD was between that of HABIT-ID and CONTROL-SD so taken together the studies represented a range of intakes from about $60 \mathrm{~g}$ protein/d to $80 \mathrm{~g}$ protein/d. The relationships between different aspects of urea kinetics were determined for the group as a whole for each of the periods of pregnancy (Table 6). The impression was obtained of a similarity in response at week 16 and week 32 which was different from week 24 . Intake was more strongly related to excretion at weeks 16 and 32 , but more strongly related to production and hydrolysis at week 24 . Production was more strongly related to excretion at week 16 and week 32 , but more strongly related to hydrolysis at week 24. At each of the time points intake plus hydrolysis was very strongly related to production and this relationship was stronger than that between intake

Table 6. Relationship between different aspects of urea kinetics in pregnant women determined by linear regression analysis*

\begin{tabular}{lcccc}
\hline \hline & Week of gestation & $r$ & Statistical significance: $P$ & Slope \\
\hline Intake $v$. production & 16 & 0.45 & 0.02 & 0.47 \\
& 24 & 0.61 & 0.001 & 0.58 \\
Intake $v$. excretion & 32 & 0.48 & 0.14 & 0.50 \\
& 16 & 0.67 & 0.0001 & 0.83 \\
Intake $v$. hydrolysis & 24 & 0.37 & 0.06 & 0.61 \\
& 32 & 0.73 & $<0.0001$ & 0.89 \\
Production $v$. excretion & 16 & -0.16 & 0.43 & 0.44 \\
& 24 & 0.42 & 0.03 & 0.36 \\
Production $v$. hydrolysis & 32 & -0.19 & $<0.0001$ & 0.85 \\
& 16 & 0.72 & 0.04 & 0.71 \\
Intake plus hydrolysis $v$. production & 24 & 0.41 & 0.0004 & 0.74 \\
& 32 & 0.64 & 0.003 & 0.79 \\
& 16 & 0.56 & $<0.0001$ & 0.89 \\
& 24 & 0.82 & 0.003 & 0.70 \\
\hline \hline
\end{tabular}

*For details of subjects and procedures, see Table 1 and pp. 166-170. 
and production. In Fig. 2, the relationship between production and either intake or intake plus hydrolysis has been shown for HABIT-ID, HABIT-SD and CONTROL-SD. It can be seen that there was a more consistent close linear relationship between production and intake plus hydrolysis, than between production and intake alone. Fig. 3 shows that for each of the three studies, HABIT-ID, HABIT-SD, CONTROL-SD there was a significant inverse linear relationship between the proportion of production which was hydrolysed and the proportion of intake which was excreted.

\section{DISCUSSION}

In the present study urea kinetics have been measured in normal pregnant women at different times during pregnancy and the response to a controlled dietary intake of protein has been observed. The controlled intake, $60 \mathrm{~g}$ protein/d, represented a relatively modest restraint, but was set at the RDA for protein at the time the study was developed (Department of Health and Social Security, 1979). More recently the reference nutrient intake for protein during pregnancy has been set at a lower level, $51 \mathrm{~g} / \mathrm{d}$ (Committee on Medical Aspects of Food Policy, 1991). The habitual protein intake for the women in HABIT-ID was $80 \mathrm{~g} / \mathrm{d}$ and for women in HABIT-SD $71 \mathrm{~g} / \mathrm{d}$. There is considerable variability between individuals of about $25 \%$ for most aspects of protein and $\mathrm{N}$ metabolism and this will tend to obscure differences between groups even where real differences might exist. It was for this reason that urea kinetics were measured twice in the same woman for HABIT-SD and CONTROL-SD. Two methods have been used for measuring urea kinetics. Primed intermittent oral doses and a single oral dose have been compared directly in the same subjects under the same conditions and have been found to give similar results (Jackson et al. 1993). In the present study there were differences in the values for urea kinetics between HABIT-ID and HABIT-SD; however, the differences were most probably the result of the differences in protein intake between the two groups of women.

When the data for all the women on the habitual and controlled intake are considered together (Tables 5 and 6, Fig. 2) the pattern of response in urea kinetics during pregnancy appears to consist of two components. On the habitual diet, at week 16, urea production, excretion and hydrolysis were not different from corresponding values for the non-pregnant state. At week 24, urea production was unchanged but a smaller proportion of production was excreted, with an increase in the proportion hydrolysed. At week 32 urea production was reduced compared with either week 16 or week 24 and was associated with a fall in urea hydrolysis compared with week 24 , to a level similar to that at either week 16 or the non-pregnant state. The response to an intake of $60 \mathrm{~g}$ protein was a modest reduction in urea production, most obvious at week 16, with relatively less of urea production being excreted and more being hydrolysed at each stage of pregnancy compared with the habitual intake.

There are two points at which control might be exerted over the fate of amino acids and $\mathrm{N}$ within the mother's body. First, there is the partitioning of amino acids between pathways which lead either to protein synthesis or to amino acid oxidation with the formation of urea (Fig. 1). The best expression we have of the relative flow to these two possible fates is urea production: $\mathrm{N}$ intake (Table 3, Figs 2 and 4). Second, the $\mathrm{N}$ which moves to urea formation has one of two possible fates determined by the partitioning of urea between urinary excretion and hydrolysis in the bowel with salvage of the $\mathrm{N}$ for further metabolic interaction. The best expressions we have of the relative flow to these possible fates is urea excretion: urea production and urea hydrolysis: urea production 


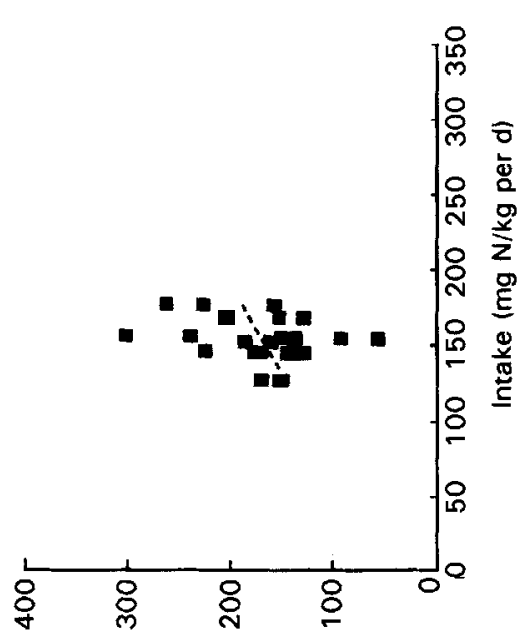

(p dad 6x/N 6u) uo!!onposd eadn

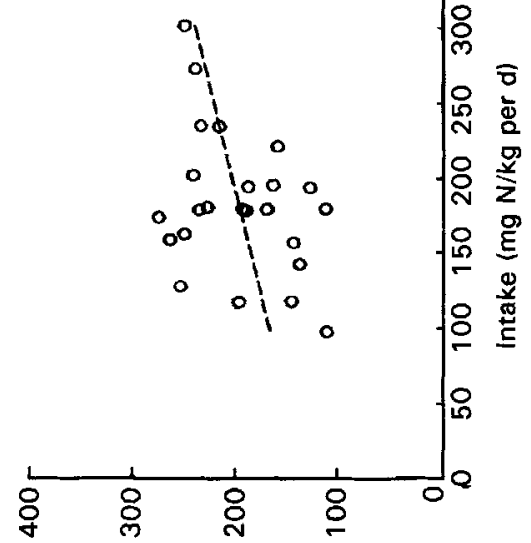

(p sad 6y/N 6u) uo!lonposd easn

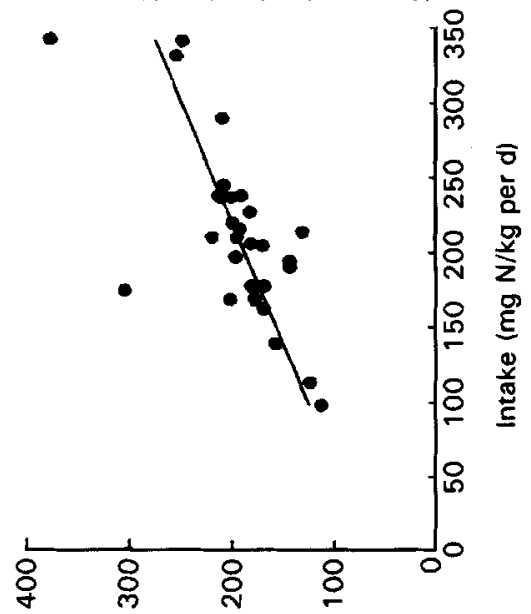

(p səd 6x/N 6u) uo!̣onpodd eəsก

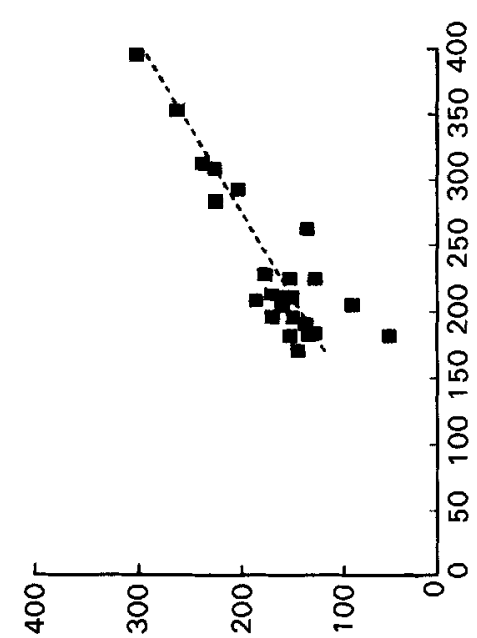

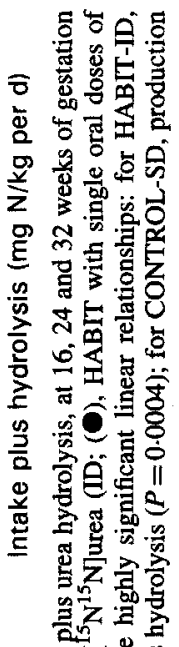

(p səd 6x/N 6u) uo!tonposd eəun

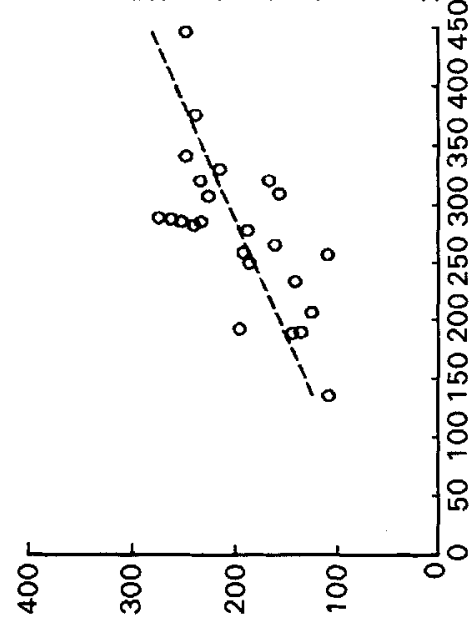

(p sad 6y/N 6u) uo!ınposd easn

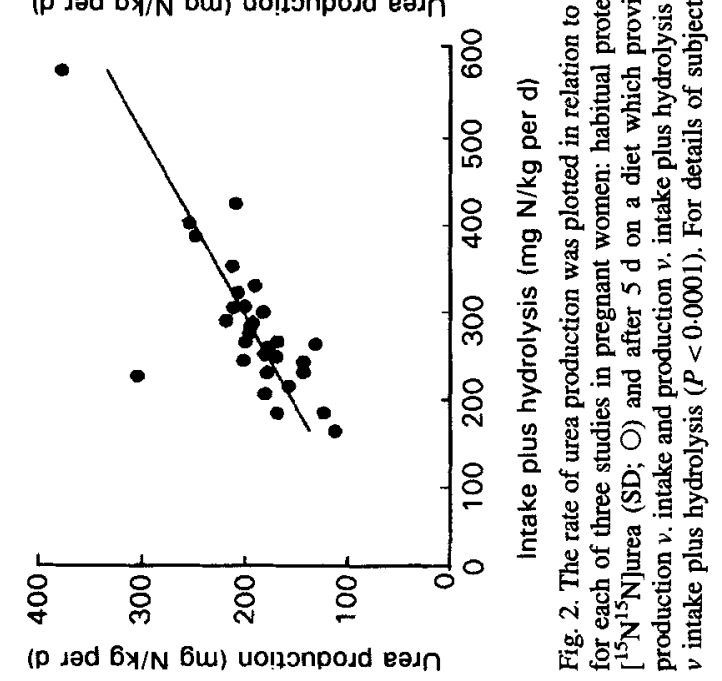



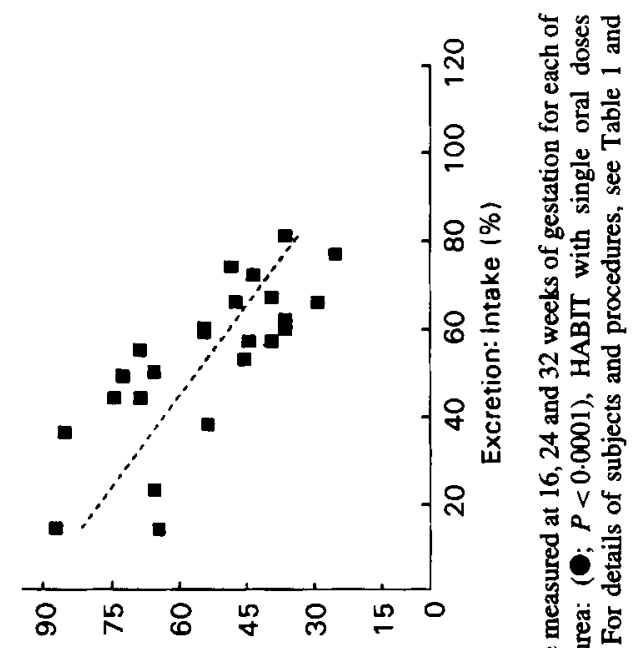

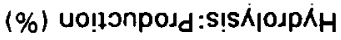

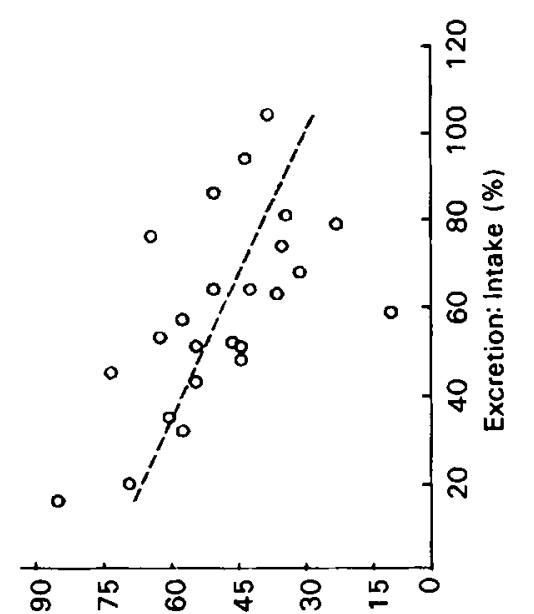

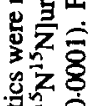

雪

苟递

용요

尊

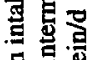

要要

刍舟京

总通尊

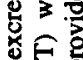

窃

窇通

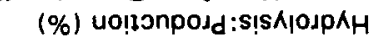

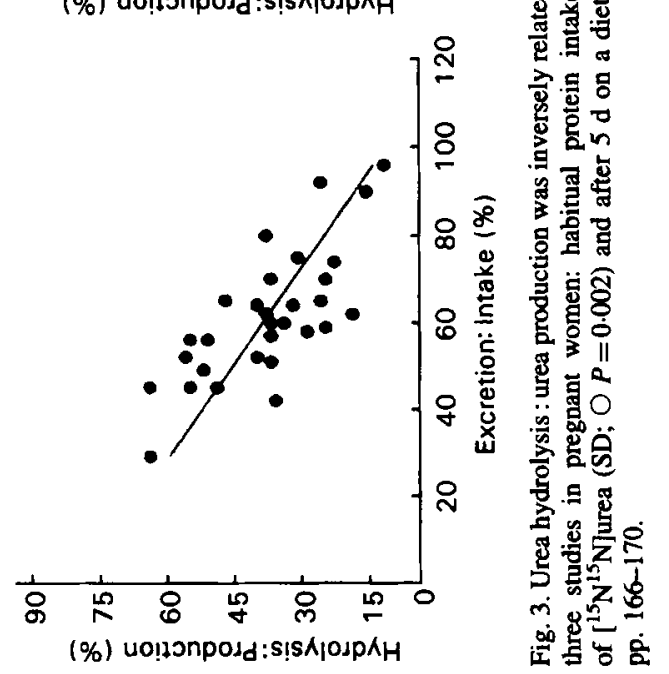



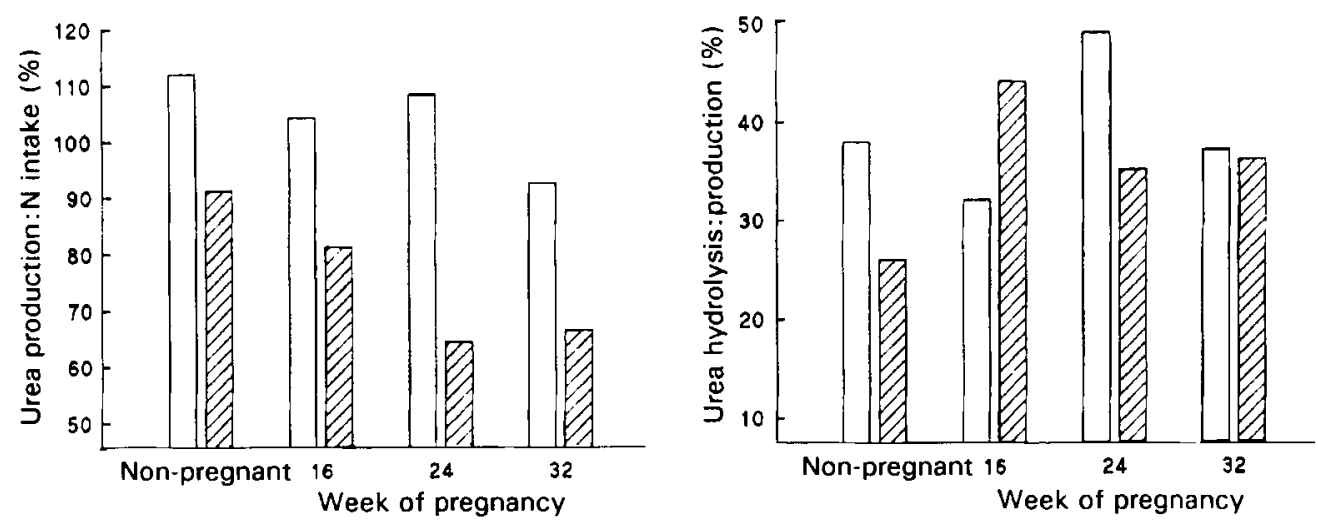

Fig. 4. Urea production, expressed in relation to the dietary intake of nitrogen, and urea hydrolysis, expressed in relation to the rate of urea production, for women in the UK ( $\square$ ), or Jamaica (ש্ Forrester et al. 1994), taking their habitual protein intake, either in non-pregnant women or during the first, second or third trimesters of pregnancy. For details of UK subjects and procedures, see Table 1 and pp. 166-170.

(Fig. 3). Of the factors which might determine the partitioning of amino acids between protein synthesis and oxidation, the need for amino acids to sustain protein synthesis is quantitatively the most important and is determined by the physiological state. The flow of amino acids to oxidative pathways is presumed to reflect an excess beyond that needed for protein synthesis (Harper et al. 1970). This excess may be a consequence of a balanced pattern of amino acids in excess of the need, or a relative mismatch between the pattern of amino acids available compared with the pattern of amino acids needed for the proteins being formed (Harper et al. 1970). Either of these options will lead to an increased flow through the oxidative pathway, giving a relatively high value for urea production: $\mathrm{N}$ intake. When the need for amino acids is not matched adequately by the intake then there is likely to be increased salvaging of urea- $\mathrm{N}$, with an increase in urea hydrolysis either in absolute terms, or as a proportion of the urea production (Picou \& Phillips, 1972; Jackson \& Wootton, 1990; Langran et al. 1992). On very-low-protein diets there is a lower limit of urea production below which the effective salvaging of urea- $\mathrm{N}$ can no longer be achieved, a urea production of approximately $150 \mathrm{mg} \mathrm{N} / \mathrm{kg}$ per $\mathrm{d}$ in normal males (Danielsen \& Jackson, 1992; Meakins \& Jackson, 1996).

The most marked changes in urea hydrolysis took place during the second trimester, on both the habitual and the controlled protein intake. Maternal weight gain was similar between weeks 16 and 24 and weeks 24 and 32. Therefore, these changes suggest that the pattern of amino acids required at this time might be qualitatively different from that during the earlier stages of pregnancy, because quantitatively absolute fetal growth is greatest in the third trimester. It is difficult to know the exact pattern of amino acids required by the developing fetus, and the demands this might place on the maternal metabolic capability. There is evidence that during the third trimester the requirements for non-essential amino acids might be particularly marked (Widdowson et al. 1979; Jackson, 1989). There is an active placento-fetal exchange of amino acids, with the placenta itself engaged in the formation of glycine and glutamine in particular (Lemons \& Schreiner, 1984; Christensen, 1992). The feto-placental exchanges of amino acids appear to be important in satisfying the energy requirements of the fetus, as well as acting as substrates for growth. In the sheep at least $40 \%$ of the energy requirements of the fetus might be derived from amino acid oxidation, with a consequent effect on the rate of urea production 
by the fetus (Jackson, 1994). In the human neonate the rate of urea production is also high, about $1.5 \mathrm{~g} \mathrm{~N} / \mathrm{kg}$ per d, similar to the rate determined in fetal sheep on a body-weight basis (Steinbrecher et al. 1996). It is not known whether the relatively high rate of amino acid oxidation in the neonate is also a reflection of a similar high dependence on amino acid oxidation to satisfy energy requirements to that seen in the fetus. However, if this were the case and the rate of amino acid oxidation in the fetus were similar to neonatal rates then urea formation in the fetus would make an important contribution to the total urea production which has been measured in the mother. For the present study, an estimate of the fetal contribution to urea production would be up to $10 \%$ in the women on their habitual protein intake during mid to late pregnancy, and up to $15 \%$ during late pregnancy in the women on the $60 \mathrm{~g}$ protein/d diet.

The results of the present study can be compared with the measurements of urea kinetics made in other studies. For pregnant women in Jamaica (Forrester et al. 1994; Fig. 4) in the non-pregnant state and at each stage of pregnancy, there is a lower value for urea production: $\mathbf{N}$ intake than for women in the $\mathrm{UK}$, indicative of a greater proportion of the available amino acids being directed towards protein synthesis than to amino acid oxidation. For women in Jamaica, the highest rates for urea hydrolysis:urea production are seen in the first trimester, whereas in the UK the highest rates were in the second trimester. As an isolated observation, this might not seem to have any particular relevance. However, when comparison is drawn between the rates of protein turnover for pregnant women in Jamaica (de Benoist et al. 1985) and the UK (Thompson \& Halliday, 1992), and the rates of urinary 5-oxoproline excretion in pregnancy between the two locations (Jackson et al. 1997), a pattern emerges of differences in the response to pregnancy of protein, amino acid and $\mathrm{N}$ metabolism between the two locations. In Jamaican women greatest changes are seen for protein turnover and salvage of urea- $\mathrm{N}$ in the first trimester, with increasing 5-Loxoprolinuria as pregnancy advances, indicative of a poorer nutritional state at the start of pregnancy and less adequate intake during pregnancy. In the UK, the nutritional status of the pregnant women enable the early demands to be accommodated and adaptive responses only become evident in the second trimester as fetal growth increases.

In the two studies where urea production rates were measured only during the third trimester of pregnancy (Kalhan et al. 1982; Olufemi et al. 1991), the rates were found to be relatively low compared with those of non-pregnant women. In the present study, if the measurements had been restricted to week 32 a similar conclusion might have been drawn. This emphasizes the importance of exploring metabolic changes at each stage of pregnancy and not assuming that the third trimester can be taken to be representative.

The relevance to general metabolism of the salvaging of urea- $\mathrm{N}$ is an open debate (Jackson, 1995). The quantities of $\mathrm{N}$ which are potentially being made available to metabolism are relatively large, for example during the second trimester the salvaged $\mathrm{N}$ was equivalent to approximately $40 \mathrm{~g}$ protein/d. The ultimate fate of this $\mathrm{N}$ has not yet been clearly defined, but if the $\mathbf{N}$ salvaged were used only to retain $\mathbf{N}$ and facilitate the formation of non-essential amino acids in the body, this might be of clinical importance for the fetus. We now have direct evidence that some of the $\mathrm{N}$ derived from urea might be used for the formation of essential amino acids by the colonic bacteria, and these may be available to the host in amounts which are of functional significance (Jackson, 1995; Yeboah et al. 1996).

There is the suggestion that the relationship between fetal growth and the risk of chronic disease, such as diabetes, hypertension and ischaemic heart disease later in life may be directly associated with maternal protein intake during pregnancy (Barker, 1992; Godfrey et al. 1996). In animal studies, the programming of metabolic competence similar 
to the changes identified in the human condition at risk of chronic diseases can be reproduced by reducing the protein content of the maternal diet to marginal levels (Langley \& Jackson, 1994). Therefore, the extent to which a mother is able to make successful adaptations to changes in her dietary protein at different stages of pregnancy, and the consequences for the growth and development of the offspring need to be explored in greater detail.

Personal support was provided as an MRC studentship to I.S.M.M.. We thank the women who participated in the studies for their cooperation and time. We are grateful to our consultant obstetric colleagues at the Princess Anne Hospital who referred women under their care to the study. The work was carried out with support from Birthright (Wellbeing). Support towards the purchase of the mass spectrometer was provided by the Rank Foundation, the Rank Prize Funds, the Hedley Trust, and the Wessex Medical Trust.

\section{REFERENCES}

Barker, D. J. P. (1992). The Fetal and Infant Origins of Adult Disease. London: BMJ Publishing Group.

Calloway, D. H. (1974). Nitrogen balance during pregnancy. In Nutrition and Fetal Development, pp. $79-94$ [M. Winnick, editor]. New York: Wiley and Sons.

Christensen, H. M. (1992). Amino acid nutrition across the placenta. Nutrition Reviews 50, 13-24.

Committee on Medical Aspects of Food Policy (1991). Dietary Reference Values for Food Energy and Nutrients for the United Kingdom. Report on Health and Social Subjects no. 41. London; H. M. Stationery Office.

Danielsen, M. \& Jackson, A. A. (1992). Limits of adaptation to a diet low in protein in normal man: urea kinetics. Clinical Science 83, 103-108.

de Benoist, B., Jackson, A. A., Hall, J. S. E. \& Persaud, C. (1985). Whole-body protein turnover in Jamaican women during normal pregnancy. Human Nutrition: Clinical Nutrition 39C, 167-179.

Department of Health and Social Security (1979). Recommended Daily Amounts of Food Energy and Nutrients for Groups of People in the UK. London: H. M. Stationery Office.

Food and Agriculture Organization/World Health Organization/United Nations University (1985). Energy and Protein Requirements. WHO Technical Report Series no. 552. Geneva: WHO.

Forrester, T., Badaloo, A. V., Persaud, C. \& Jackson, A. A. (1994). Urea production and salvage during pregnancy in normal Jamaican women. American Journal of Clinical Nutrition 60, 341-346.

Godfrey, K., Robinson, S., Barker, D. J. P., Osmond, C. \& Cox, V. (1996). Maternal nutrition in early and late pregnancy in relation to placental and fetal growth. British Medical Joumal 312, 410-414.

Graham, D. Y., Klein, P. D., Evans, D. J., Evans, D. G., Alpert, L. C., Opekun, A. R. \& Boutton, T. W. (1987). Campylobacter pylori detected non-invasively by the ${ }^{13} \mathrm{C}$-urea breath test. Lancet i, 1174-1177.

Harper, A. E., Benevenga, N. J. \& Wohlhueter, R. M. (1970). Effects of ingestion of disproportionate amounts of amino acids. Physiological Reviews 50, 428-458.

Hibbert, J. M., Forrester, T. \& Jackson, A. A. (1992). Urea kinetics: comparison of oral and intravenous dose regimens. European Journal of Clinical Nutrition 45, 405-409.

Hytten, H. E. \& Leitch, I. (1971). The Physiology of Human Pregnancy. Oxford: Blackwell Scientific Publications.

Jackson, A. A. (1989). Optimizing amino acid and protein supply and utilization in the newborn. Proceedings of the Nutrition Society 48, 293-301.

Jackson, A. A. (1993). Chronic malnutrition: protein metabolism. Proceedings of the Nutrition Sociery 52, 1-10.

Jackson, A. A. (1994). Urea as a nutrient: bioavailability and role in nitrogen economy. Archives of Disease in Childhood 70, 3-4.

Jackson, A. A. (1995). Salvage of urea-nitrogen and protein requirements. Proceedings of the Nutrition Society 54, 535-547.

Jackson, A. A., Danielsen, M. S. \& Boyes, S. (1993). A non-invasive method for measuring urea kinetics with a single dose of $\left[{ }^{15} \mathrm{~N}^{15} \mathrm{~N}\right] \mathrm{urea}$ in free-living humans. Joumal of Nutrition 123, 2129-2136.

Jackson, A. A., Golden, M. H. N., Jahoor, P. F. \& Landman, J. P. (1980). The isolation of urea-N and ammonia$\mathrm{N}$ from biological samples for mass spectrometry. Analytical Biochemistry 105, 14-17.

Jackson, A. A., Persaud, C., Werkmeister, G., McClelland, I. S. M., Badaloo, A. \& Forrester, T. (1997). Comparison of urinary 5-L-oxoproline ( $\mathrm{L}$-pyroglutamate) during normal pregnancy in women in England and Jamaica. British Journal of Nutrition 77, 183-196.

Jackson, A. A., Picou, D. \& Landman, J. (1984). The non-invasive measurement of urea kinetics in normal man by a constant infusion of ${ }^{15} \mathrm{~N}^{15} \mathrm{~N}$-urea. Human Nutrition: Clinical Nutrition $38 \mathrm{C}, 339-354$. 
Jackson, A. A. \& Wootton, S. A. (1990). The energy requirements of growth and catch-up growth. In Activity, Energy Expenditure and Energy Requirements of Infants and Children, pp. 185-214. [B. Schurch and N. S. Scrimshaw, editors]. Lausanne, Switzerland: IDECG.

Johnstone, F. D., Campbell, D. M. \& MacGillvray, I. (1981). Nitrogen balance studies in human pregnancy. Joumal of Nutrition 111, 1884-1893.

Kalhan, S. C., Tserng, K. Y., Gilfillan, C. \& Dierker, L. J. (1982). Metabolism of urea and glucose in normal and diabetic pregnancy. Metabolism 31, 824-833.

Kaplan, A. (1965). Urea nitrogen and ammonia nitrogen. In Standard Methods in Clinical Chemistry, pp. 245256 [S. Meites, editor]. New York: Academic Press.

King, J. C. (1975). Protein metabolism during pregnancy. Clinics in Perinatology 2, 243-254.

Kramer, M. S. (1987). Determinants of low birthweight: methodological assessment and meta-analysis. Bulletin of the World Health Organization 65, 663-737.

Langley, S. C. \& Jackson, A. A. (1994). Increased systolic blood presure in adult rats caused by fetal exposure to matemal low protein diets. Clinical Science 86, 217-222.

Langran, M., Moran, B. J., Murphy, J. L. \& Jackson, A. A. (1992). Adaptation to a diet low in protein: effect of complex carbohydrate upon urea kinetics in normal man. Clinical Science 82, 191-198.

Lemons, J. A. \& Schreiner, R. L. (1984). Metabolic balance of the ovine fetus during the fed and fasted states. Annals of Nutrition and Metabolism 28, 268-280.

McClelland, I. S. M. \& Jackson, A. A. (1996). Urea kinetics in healthy young women: minimal effect of stage of menstrual cycle, contraceptive pill and protein intake. British Joumal of Nutrition 76, 199-209.

Mayel-Afshar, S. \& Grimble, F. R. (1983). Changes in protein turnover during gestation in the foetuses, placentas, liver, muscle and whole body of rats given low protein diet. Biochimica et Biophysica Acta 756, $182-190$.

Meakins, T. S. \& Jackson, A. A. (1996). Salvage of exogenous urea-nitrogen enhances nitrogen balance in normal men consuming marginally inadequate protein diets. Clinical Science 90, 215-225.

Millward, D. J. (1992). The metabolic basis of amino acid requirements. In Protein-energy Interactions, pp. 3136 [N. S. Scrimshaw and B. Schurch, editors]. Vevey, Switzerland: IDECG

Naismith, D. J. \& Morgan, B. L. G. (1976). The biphasic nature of protein metabolism during pregnancy in the rat. British Joumal of Nutrition 36, 563-566.

National Academy of Sciences (1990). Nutrition During Pregnancy Part 1, Weight Gain. Washington, DC: National Academy Press.

Olufemi, O. S., Whittaker, P. G. \& Lind, T. (1991). Glycine and urea metabolism during normal and diabetic pregnancies. Proceedings of the Nutrition Society 50, $200 \mathrm{~A}$.

Picou, D. \& Phillips, M. (1972). Urea metabolism in malnourished and recovered children receiving a high or a low protein diet. American Joumal of Clinical Nutrition 25, 1261-1266.

Rand, W. M., Uauy, R. \& Scrimshaw, N. S. (1984). Protein-energy-requirement studies in developing countries: results of intemational research. Food and Nutrition Bulletin Suppl. 10.

Rush, D. (1989). Effects of changes in maternal energy and protein intake during pregnancy, with special reference to fetal growth. In Fetal Growth, pp. 203-229 [F. Sharpe, R. B. Fraser and R. D. G. Milner, editors]. London: Springer-Verlag.

Steinbrecher, H. A., Griffiths, D. M. \& Jackson, A. A. (1996). Urea kinetics in normal breast-fed infants measured with ${ }^{15} \mathrm{~N}^{15} \mathrm{~N}$-urea. Acta Paediatrica 85, 656-662.

Thompson, G. N. \& Halliday, D. (1992). Protein turnover in pregnancy. European Journal of Clinical Nutrition 46, 411-417.

Walser, M., George, J. \& Bodenios, L. J. (1954). Altered proportions of isotopes of molecular nitrogen from biological samples for mass spectrometry. Joumal of Chemistry and Physics 22, 1146.

Widdowson, E. M., Southgate, D. A. T. \& Hey, E. M. (1979). Body composition of the fetus and infant. In Nutrition and Metabolism of the Fetus and Infant, pp. 169-177 [H. A. K. Visser, editor]. The Hague: Martinus Nijhoff.

Yeboah, N., Ah-Sing, E., Badaloo, A., Forrester, T., Jackson, A. \& Millward, D. J. (1996). Transfer of ${ }^{15} \mathrm{~N}$ from urea to the circulating lysine pool in the human infant. Proceedings of the Nutrition Society 55, 37A.

Young, V. R., Bier, D. M. \& Pellet, P. L. (1989). A theoretical basis for increasing current estimates of the amino acid requirements in adult men, with experimental support. American Joumal of Clinical Nutrition $\mathbf{5 0}$ 80-92. 